\title{
The Innovation of Learning Mathematics on Introduction of Number for Pre-School Students
}

\author{
Hawa Liberna $^{(*)}$, Yoga Budi Bhakti, Irnin Agustina Dwi Astuti \\ Universitas Indraprasta PGRI, Jl. Raya Gedong No.80, Jakarta Timur, Indonesia
}

\begin{abstract}
Received: September 24, 2020 The use of technology in learning is very important according to the Revised: December 22, 2020 development of the times. However, the application of technology as a Accepted: February 13, 2021 learning medium is still limited. The purpose of this research is to develop interactive multimedia Mathematics to improve the learning motivation of early childhood. This research method employed ADDIE model, consisting of four stages: analyzing, designing, developing, implementing, and evaluating. Instrument of this reserach used validation sheets and response questionnaires. Expert validation was used to validate media consisting of media validation, material validation, and language validation, while students' response questionnaires determined practicality. Average validation results from material experts of 3.4, media experts of 3.2 , and language expert of 3.3. So that if averaged all, then the validation of Mathematics learning media is 3.3 with good categories. Moreover, the practicality of media also shows that it can be easily applied. The observation data also supports the effectiveness of the media during the implementation. The result shows that the media is confirmed to be effective as it can improve the students' learning motivation.
\end{abstract}

Keywords: Learning Mathematics, introduction of number, learning motivation, preschool students.

(*) Corresponding Author: liberna_h@yahoo.com

How to Cite: Liberna, H., Bhakti, Y. B., \& Astuti, I. A. D. (2021). The innovation of learning mathematics on introduction of number for pre-school students. Formatif: Jurnal Ilmiah Pendidikan MIPA,11 (1): 71-82. http://dx.doi.org/10.30998/formatif.v11i1.7623

\section{INTRODUCTION}

Education begins and is instilled starting from someone is still very early. This will result in superior generations and quality of human resources in the future. The quality of human resources is what will be indispensable in the development of a nation. Early childhood education is a thorough process of fostering child's development from birth to six years that covers physical and nonphysical aspects by providing stimulation for physical, spiritual, motor, mind, emotional, and social development that is appropriate for the child to grow and to develop optimally (MacArtney and Morton, 2013). Early age is also said to be a creative period that is believed that creativity shown by children is an original form of creativity with the frequency of its appearance as if uncontrollably. It is also a unique phase of life with distinctive characteristics, both physical, psychic, social, and moral. This characteristic is characterized by the child's exceptional learning ability, namely the child's desire to learn actively and exploratoryly (Taufik, Apendi, Saidi, and Istiarsono, 2019). One of the subjects that has been introduced to early childhood is Mathematics. Mathematics has a very important role in life. Mathematical abilities can be used by a person to solve problems they face in daily life (Astuti, Leonard, Bhakti, and Astuti, 2019). Early childhood is a very strategic time to introduce numbers and to count on the Math path. Children at this age are very sensitive to excitatory received from the 
environment (Aulina, 2018). If the learning of Mathematics is given through activities that suit the interests, needs, and abilities of the child then the child will be more successful in mastering the ability to learn Mathematics such as knowing numbers and counting (Ayuni and Setiawati, 2019).

But in reality, the child's ability to learn Mathematics is still low, especially in the introduction of numbers (DS and Setiawan, 2013). This is based on observations from a number of PAUD and kindergarten schools in Bojonggede sub-district, Bogor. Some children at the time of learning still have a lack understanding in counting, knowing and sorting numbers. It is caused by learning media based only on books that make children bored. The limitations in conveying information in the form of concrete objects are also a problem faced, so the motivation of children's learning is also low.

Good and adequate media utilization is expected to stimulate students' thoughts, attention and interests so that the learning process is good and enjoyable (Ljubojevic, Vaskovic, Stankovic, and Vaskovic, 2014). Children need a learning medium that suits their needs and creativity so that they do not get bored in learning and can increase their imagination (Fitria, 2018). One of the things that can be developed is to use interactive multimedia-based learning media.

Right now, we do not get away with technology, especially information and communication technology. That is what happens in education. The revolution of science and technology, understanding how students learn, the advancement of communication and information media and so on give their own meaning to educational activities (Wood and Ashfield, 2008). With interactive multimedia-based learning media, children will be easier to get, to know and to develop skills through computers.

Today's widely developed interactive multimedia proves that computers can assist teachers in teaching and students in learning. It is necessary to develop interactive multimedia for early students in order to produce learning resources that can foster interest, attract, can provide motivation, are easy to learn, and are relevant to the needs of the learning process teaching in the classroom. The purpose of this research is to develop interactive multimedia Mathematics and to improve the learning motivation of early childhood.

\section{METHODS}

This research was a development research, which produced a product in the form of learning media. Then, the product was tested for validity and students respons. The participants in this study were 33 of 10th-grade students at one of the public vocational schools in Jember, East Java. This study used the Thiagarajan model or known as the ADDIE model, consisting of five stages: analyzing, designing, developing, implementing, and evaluating. In the analyzing stage, observations and interviews were carried out to determine the needs in learning process by conducting initial analysis activities, media analysis, and formulation of learning objectives. The designing stage prepared the learning media design through several steps, i.e., media selection, format selection, the initial design of the media, and the preparation stage. Learning motivation questionnaire determined the needs of the learning motivation questionnaire. Then, the validation and test were carried out at the developing stage.

This learning medium was validated by people who are experts in the field, namely media validation, material validation, and language validation. Media expert assessment consisted of aspects of display, running program, and ease of use. Material expert assessment consisted of aspects of material suitability, drawing, material understanding. The assessment of linguists consisted of aspects of language and the ease 
of language. After the assessment of the learning media then the learning media was revised in accordance to the advice of the validator. The next stage was the implementation stage. Learning media was implemented to students to see how it affected students' learning motivation. The learning motivation was obtained from the N-Gain.

\section{RESULTS \& DISCUSSION}

\section{Results}

The learning media is developed using four stages of ADDIE model: analyzing, designing, developing, implementing, and evaluating. In analyzing stage, based on the results of interviews with teachers, many students are still lack focus because they cannot study for a long time, only about 5 minutes. Some children also find it difficult to add up, to count and to sort numbers. This is caused by inappropriate learning media. They need new and interesting learning media that can increase interest in learning Mathematics. The basic competencies that must be achieved in learning Mathematics for early childhood are number of recognition, addition, subtraction, and sequence numbers.

The steps in the design stage are determining the purpose of using the media, determining the learning material that refers to the analysis stage. At this stage, flowchart views and storyboards are also made, as well as determining the tools and applications that will be used in making learning media. The equipment used in making interactive multimedia-based learning media is a computer or laptop and earphones, and the applications used are Adobe Flash CS3, Adobe Photoshop CS3, Adobe Audition 3.0, CorelDRAW X4. The Adobe Flash CS3 application is used for making the main media, Adobe Photoshop CS3 and CorelDRAW X4 are used to modify the Background and Clipart, while Adobe Audition 3.0 is used to record the author's voice to be used as audio in interactive multimedia-based learning media.

The themes that will be used in making interactive multimedia-based learning media are fruits and vegetables so that children will attract and like them. The clipart used consisting of various pictures of vegetables and fruits. The background used varies from one slide to another.

The results of initial product development in the form of interactive multimediabased learning media are developed based on the making of designs and with the materials that have been collected. Interactive multimedia-based Mathematics learning media consists of 11 slides interconnected with navigation buttons. Some discussions come with audio to clarify material and animations to add media appeal. The themes used are vegetables and fruits assuming that children know more about various fruits and vegetables. The background used is varied and colorful so that the child does not get bored in learning.

The audio used is the author's voice in the form of a narrative and recorded using the Adobe Audition 3.0 application. Some audios are downloaded from the internet such as the sound when a button is pressed. For background images and clipart, some are downloaded from the internet without changing, some are downloaded from the internet but are modified again using Adobe Photoshop CS3 and CorelDRAW X4.

The initial visual appearance of interactive multimedia-based Mathematics learning media before being validated by experts and revised is shown figure 1 . 


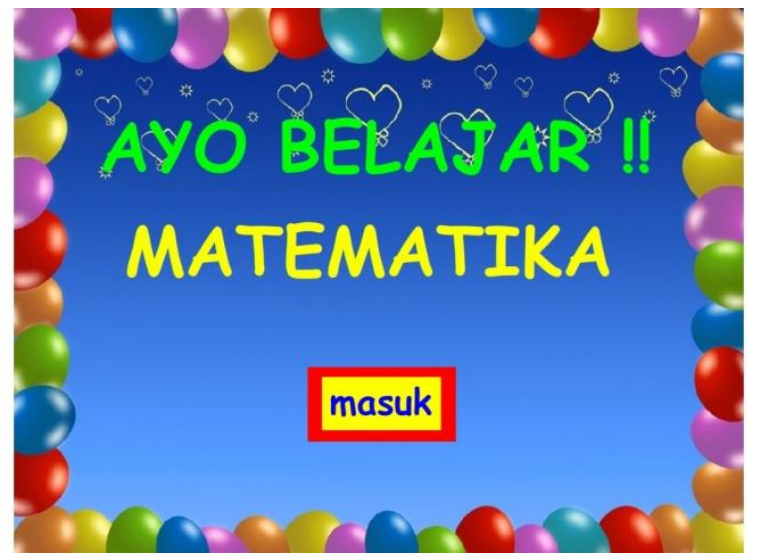

Figure 1. Display of Home Page

When the interactive multimedia-based Mathematics learning media is first opened, an intro screen will appear containing the words "Ayo Belajar Matematika", and there is an audio or a narration. After that there will be an "enter" button which when clicked will direct the user to the main menu.

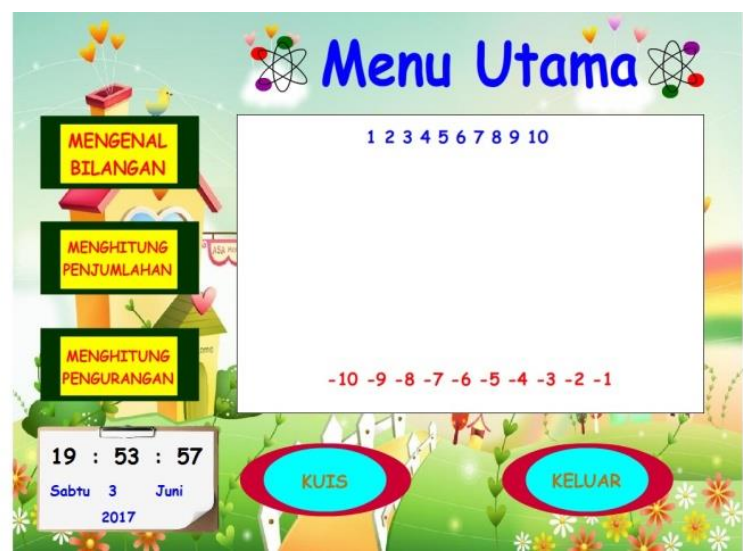

Figure 2. Display of Main Menu

On the main menu display, there are material buttons "Mengenal Bilangan", "Menghitung Penjumlahan", "Menghitung Pengurangan" which when clicked will enter the selected material slide. There is also a "Quiz" button which when clicked will enter various practice questions and games, and a "Quit" button. In the main menu display, animation effects such as animated digital clocks and dates are also given to add attractiveness.

On the slide about knowing numbers, there is an opening scene before going into the discussion, in which there is an audio narration. In the opening scene, there is a "start" button which when it is clicked, will enter the discussion scene. In each discussion scene there are play, next, and prev buttons. The play button will enter the simulation scene, and the next and prev buttons will enter other discussion scene. The simulation scene is filled with audio and animation narration.

In the material of calculating the addition is divided into two parts, namely the addition of 2 numbers and the addition of 3 numbers. Even so, the concept of the discussion of the two remains the same. When entering the additive material, the user will enter a display that contains the options "Penjumlahan 2 Angka" and "Penjumlahan 3 Angka". 

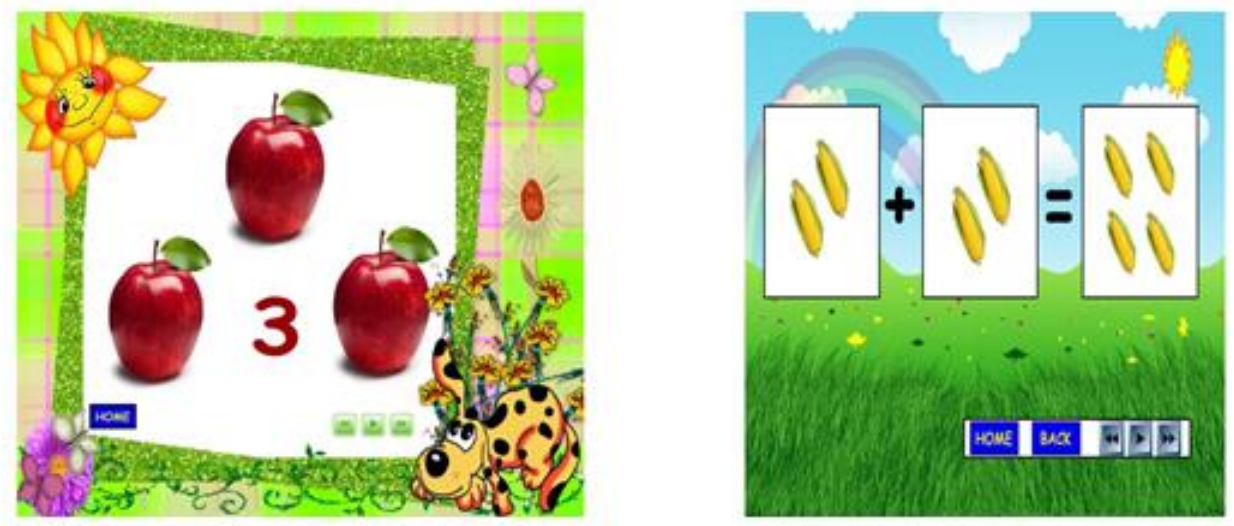

Figure 3. Display of Contents

The simulation scene in subtraction material is somewhat different from the simulation scene in summation material. The subtraction material contains more animation and audio narration. The animation used is a simulation of fruit falling from a tree. The fruit that falls from the tree is the deduction and the fruit that is still on the tree is the reminder or the answer. In each discussion scene and simulation scene, there is a "Home" button which when it is clicked, it will return to the main menu.

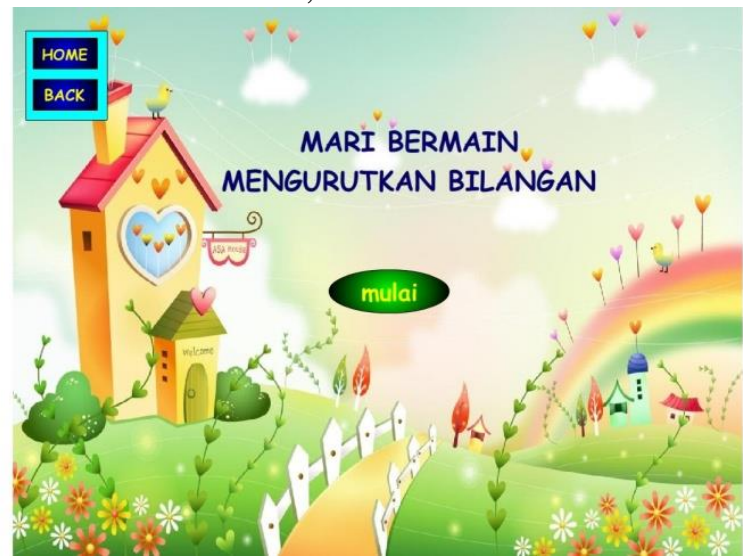

Figure 4. Display of Quiz

Quizzes are form of questions and games. The quiz consists of playing number sequences, counting quiz, and guessing pictures of quiz. When entering the Quiz slide for the first time, it will enter the display options "Playing by Numbers", "Counting Quiz", and "Guessing Pictures Quiz".

The media that has been made is then validated to obtain data regarding to responses from media experts, material experts, and linguists about interactive multimedia-based Mathematics learning media products for early childhood. Validation is carried out in order to obtain the feasibility of the media for use in trial activities. In addition to assessing products, media experts, material experts, and linguists also provide criticism and suggestions for improving interactive multimedia-based Mathematics learning media. The results of the assessment and expert advice are used as the basis for revising the initial product before being field tested. 
Table 1. Result of Media Expert

\begin{tabular}{|c|c|c|}
\hline No & Indicators & Score \\
\hline 1 & Text legibility & 4 \\
\hline 2 & Sound quality & 3 \\
\hline 3 & Image display quality & 4 \\
\hline 4 & Animation display quality & 3 \\
\hline 5 & Colour composition & 3 \\
\hline 6 & Clarity of navigation keys & 4 \\
\hline 7 & The layout of slide & 3 \\
\hline 8 & The unity of each element & 3 \\
\hline \multirow[t]{3}{*}{9} & Animation and sound compatibility & 3 \\
\hline & Ease of use & 4 \\
\hline & Average score & 3,4 \\
\hline
\end{tabular}

From the results of the data in table 1, the results of media validation is in the "Very Good" category with an average rating of the media that is 3.4. The average value also shows that interactive multimedia-based Mathematics learning media for early childhood are feasible to be produced and tested.

Table 2. Result of Material Expert

\begin{tabular}{clc}
\hline No & \multicolumn{1}{c}{ Indicators } & Score \\
\hline 1 & Clarity of the title and target of program users. & 4 \\
2 & The attraction of material in motivating early childhood & 3 \\
3 & $\begin{array}{l}\text { Clarity of content } \\
4\end{array}$ & 3 \\
& $\begin{array}{l}\text { The suitability of the material with the early childhood } \\
\text { curriculum. }\end{array}$ & 4 \\
6 & $\begin{array}{l}\text { Clarity of discussion sequence } \\
7\end{array}$ & 3 \\
8 & $\begin{array}{l}\text { Clarity of information on image illustrations. } \\
9\end{array}$ & 3 \\
10 & $\begin{array}{l}\text { Clarity of information in each discussion. } \\
\text { The accuracy of the material in the introduction of }\end{array}$ & 3 \\
& Mathematics for early childhood. & 3 \\
\hline
\end{tabular}

From the results of the data in table 2 the results of material validation are in the "Good" category with an average rating of the media that is 3,2. The average value also shows that interactive multimedia-based Mathematics learning media for early childhood are feasible to be produced and tested.

From the data in table 3, the results of the language validation are in the "Good" category with an average assessment of the media that is 3,3. The average value also shows that interactive multimedia-based Mathematics learning media for early childhood are feasible to be produced and tested. 
Table 3. Result of Language Expert

\begin{tabular}{clc}
\hline No & \multicolumn{1}{c}{ Indicators } & Score \\
\hline 1 & The clarity of the language use & 3 \\
2 & Suitability of the language use & 3 \\
3 & Accuracy in word selection & 3 \\
4 & The accuracy of sentence structure & 3 \\
5 & The effectiveness of sentences & 4 \\
6 & The stickiness of the word & 3 \\
7 & The ability to provide motivation & 4 \\
8 & The ability to encourage interest in learning & 4 \\
9 & Word legibility & 3 \\
10 & The accuracy of using language rules for early childhood & 3 \\
& & Score Average
\end{tabular}

The interactive multimedia-based Mathematics learning media trial is carried out by a group of 10 children aged 4-6 years. During the trial product, the researchers explain the interactive multimedia-based Mathematics learning media to the selected early childhood groups. After the interactive multimedia-based learning media has been explained and given instructions on how to use it, the researchers ask the early childhood group to carry out learning using interactive multimedia-based Mathematics learning media accompanied by a companion teacher. Based on student's response results, an average score of 3.6 is obtained. This states that students love learning with interactive multimedia and have a positive response to learning media.

Table 4. Score of Learning Motivation Before and After Treatment

\begin{tabular}{cc}
\hline Aspect of Learning Motivation & Score Average \\
\hline Before treatment & 50 \\
\hline After treatment & 82 \\
\hline
\end{tabular}

The effectiveness of learning media is obtained based on the N-Gain of learning motivation questionnaire before and after using media. Table 4 shows that the N-Gain of the students' learning motivation is 50 before using media and 82 after using media. Hence, the average value of $\mathrm{N}$-gain is 0,64 , which is in the range of $0.3 \leq \mathrm{g} \leq 0.7$. Based on the criteria in N-Gain, the category of media effectiveness is middle. students' learning motivation increases after learning Mathematics with multimedia, many students are active in Mathematics learning. Thus, the learning media can increase student's learning motivation.

\section{Discussion}

The development of technology at this time, information becomes a very important need. To spur progress in the field of information, the right information is required, fast and accurate. With the rapid development of technology, in the world of education is needed learning media through the field of IT (Mutia, Gimin, and Mahdum, 2020). Therefore, it is felt that the use of the system in a learning is very necessary, in order to turn boring and monotous formal learning into educational and fun learning through interactive learning media innovation. In early childhood, it is a very suitable time to introduce Math numbers. Rendi, et. al. argue that learning media is all physical tools that 
can present messages and stimulate students to learn (Rendi, Sumaryati, and Purwanti, 2020).

Interactive multimedia-based Mathematics learning media that has been validated by media experts, material experts, and linguists and is declared worthy of being tested in the field. At this stage of implementation, product trials are carried out. Learning media trials were carried out with the aim of knowing every detail of the shortcomings and weaknesses of the finished media, to see the effectiveness of the media when used by the intended students. The development of learning media using Articulate Storyline software is carried out to improve the students' learning motivation. Children's psychomotor levels when at school are very active. They would love to know what they see. Their curiosity is also high, so everything new they want to learn (Fithri and Setiawan, 2017). Learning media is one of the things that children love, because it is very attractive, innovative, and fun. Naturally, children always want to know everything. They explore concepts when interacting with their environment (Nofriyanti and Sari, 2019). Both digital and nondigital media can extend the knowledge that which can be done from the childhood (Alper, 2013).

The teachers and students provide a positive response to the learning media produced. This media can make learning enjoyable and comfortable for students to understand the knowing number. According to Jan (2018), learning by utilizing technology can create a more collaborative and engaging learning environment. Learning using media can provide more relaxed conditions felt by children when learning, with this children will not experience a fatigue of learning because the material presented in this game model is really a form of a game (Mostowfi, Mamaghani, and Khorramar, 2016; Rahmayanti, Oktaviani, and Syani, 2020). Based on the result, educational games that are used as learning media, besides being able to increase learning motivation (Foster, 2008), can also improve student outcomes (Ningrum, 2018; Syawaluddin, Afriani Rachman, and Khaerunnisa, 2020).

Learning Mathematics with learning media not only improves students' learning motivation, but improves students' understanding of Mathematics (Rahayu, Masrukhan, and Sugianto, 2019; Tella, 2007). With learning through media, students are very enthusiastic and active to learn Mathematics (Nasir and Nirfayanti, 2020). Learning media not only changes the motivation but students' learning activities and styles are also better. According to Fatahillah, et. al. (Fatahillah, Puspitasari, and Hussen, 2020), the students can understand the process of retrieving learning information using the learning media. They can access Schoology easily by entering the class access code and open and press the buttons available on GeoGebra linked to Schoology to get available learning information. It is also confirmed by Umar and Jalil, who stated that the internet facility contributes to develop students' abilities in using the computer (Umar and Jalil, 2012). This instruction makes it easy for the students to operate so that this media is the appropriate technological device to improve the students' ICT literacy (Jan, 2018).

Interactive learning media with the audiovisual display is very interesting for students to learn (Rachmadtullah, Ms, and Sumantri, 2018; Rubiyah, Dasmo, and Suhendri, 2020). Students prefer learning media that can display funny images and colorful views. The presence of video and audio also increases the spirit of students in learning because students can listen to the material explanation clearly, thereby reducing the misconceptions of the subject matter. The learning media can affect student's learning motivation while working on evaluation quations (Bhakti, Astuti, and Rahmawati, 2020; Wardani, Puspitawedana, and Isnawati, 2020). The results are consistent with a cognitive theory of multimedia learning and yield principles for the design of interactive multimedia learning environments (Mayer, Dow, and Mayer, 2003). The benefits of learning media are to clarify the presentation of learning content while attracting the 
attention of students and improving learning motivation to impact the students' learning outcomes (Wulandari, Mujib, and Putra, 2016).

Further, similar to Olive, et. al. (Olive, et. al., 2009) suggest that technology can transform the students, teacher, and Mathematic by using developmentally appropriate interactions among students, teachers, tasks, and technologies. In this aspect, the technology in education must be used to transform learning and not simply to replace traditional worksheets with digital screens without current classroom practices (Papadakis, Kalogiannakis, and Zaranis, 2016). The use of mobile technologies in Mathematics education has the potential to encourage meaningful students' engagement with Mathematics, by embedding the subject in authentic contexts (Bos and Lee, 2013; Bray and Tangney, 2016). When well designed, this technology can offer meaningful opportunities for young children to engage with STEM content, learn through exploration, and practice newly acquired skills (Aladé, Lauricella, Beaudoin-Ryan, and Wartella, 2016). Ideally, mobile technologies should be integrated in Mathematics teaching and learning to create a new learning. For this to happen apps must be developmentally appropriate, applicable, and appealing.

Interactive multimedia-based Mathematics learning media developed has flexible properties. This interactive learning media allows users to choose the content of each subject matter presented. Interactive multimedia-based Mathematics learning media can be utilized in the classroom and individually (Amir, Hasanah, and Musthofa, 2018; Tsany, Septian, and Komala, 2020). Interactive multimedia-based Mathematics learning media has flexibility also in the use of time. Children are easy to learn by themselves because the media is interactive and easy to use by early childhood.

According to Hartati, this is by the characteristics of early childhood expressed as follows: 1) having great curiosity, 2) being a unique person, 3) fantasizing and imagining 4) potential period to learn, 5) having egocentric attitudes, 6) having a short concentration vulnerable power, 7) being part of social beings (Hartati, 2005). Through interactive multimedia-based Mathematics learning media can also introduce children to the computer (Chen and Chang, 2006; Papadakis, Kalogiannakis, and Zaranis, 2018). Early childhood is the best and most effective time to introduce children to computer activities (Bolstad, 2004; De Haan, Elbers, and Leseman, 2014). Getting to know computers can help them learn to follow commands regularly, teach them to be patient, hone their fine motor and support intelligence with educational games. Children can feel the pleasure of using interactive multimedia-based Mathematics learning media. Therefore, it is hoped that this learning media can help improve the quality of children's learning and can increase children's motivation in learning Mathematics.

\section{CONCLUSION}

The process of media development consists of four stages: defining, designing, developing, and disseminating. Average validation results from material experts of 3.4, media experts of 3.2, and linguists of 3.3. So that if averaged all, then the validation of Mathematics learning media is 3.3 with good categories. Moreover, the practicality of media also shows that it can be easily applied. Furthermore, the effectiveness of learning media is obtained from the $\mathrm{N}$-Gain average learning motivation questionnaire. The observation data also supports the effectiveness of the media during the implementation. The result shows that the media is confirmed to be effective as it can improve the students' learning motivation. Mathematics interactive multimedia is one of the media by utilizing appropriate technology in the learning process to enhance students' learning motivation. 


\section{REFERENCES}

Aladé, F., Lauricella, A. R., Beaudoin-Ryan, L., \& Wartella, E. (2016). Measuring with Murray: Touchscreen technology and preschoolers' STEM learning. Computers in Human Behavior, 62, 433-441. https://doi.org/10.1016/j.chb.2016.03.080

Alper, M. (2013). Developmentally appropriate New Media Literacies: Supporting cultural competencies and social skills in early childhood education. Journal of Early Childhood Literacy, 13(2), 175-196. https://doi.org/10.1177/1468798411430101

Amir, M. F., Hasanah, F. N., \& Musthofa, H. (2018). Interactive Multimedia Based Mathematics Problem Solving to Develop Student s' Reasoning. Int. J. Eng. Technol, 7(2.14), 272-276.

Astuti, D. P., Leonard, L., Bhakti, Y. B., \& Astuti, I. A. D. (2019). Developing Adobe Flash-based mathematics learning media for 7 th -grade students of junior high school. Journal of Physics: Conference Series, 1188(1), 012098. https://doi.org/10.1088/1742-6596/1188/1/012098

Aulina, C. N. (2018). Penerapan Metode Whole Brain Teaching dalam Meningkatkan Motivasi Belajar Anak Usia Dini. Jurnal Obsesi: Jurnal Pendidikan Anak Usia Dini, 2(1), 1. https://doi.org/10.31004/obsesi.v2i1.1

Ayuni, D., \& Setiawati, F. A. (2019). Kebun Buah Learning Media for Early Childhood Counting Ability. Jurnal Obsesi: Jurnal Pendidikan Anak Usia Dini, 3(1), 1. https://doi.org/10.31004/obsesi.v3i1.128

Bhakti, Y. B., Astuti, I. A. D., \& Rahmawati, E. Y. (2020). Improving Students' Problem Solving Ability Through Learning Based Videoscribe. JIPF (Jurnal Ilmu Pendidikan Fisika), 5(2), 61. https://doi.org/10.26737/jipf.v5i2.1595

Bolstad, R. (2004). The role and potential of ICT in early childhood education: A review of New Zealand and international literature. Ministry of Education Wellington.

Bos, B., \& Lee, K. (2013). Mathematics apps and mobile learning. Society for Information Technology \& Teacher Education International Conference, 36543660. Association for the Advancement of Computing in Education (AACE).

Bray, A., \& Tangney, B. (2016). Enhancing student engagement through the affordances of mobile technology: a 21st century learning perspective on Realistic Mathematics Education. Mathematics Education Research Journal, 28(1), 173-197.

Chen, J.-Q., \& Chang, C. (2006). Using computers in early childhood classrooms: Teachers' attitudes, skills and practices. Journal of Early Childhood Research, 4(2), 169-188.

De Haan, A. K. E., Elbers, E., \& Leseman, P. P. M. (2014). Teacher-and child-managed academic activities in preschool and kindergarten and their influence on children's gains in emergent academic skills. Journal of Research in Childhood Education, 28(1), 43-58.

DS, S. H., \& Setiawan, T. (2013). Sikap Guru Taman Kanak-Kanak Terhadap Pembelajaran Matematika. Jurnal Ilmu Pendidikan, 19(1), 50-55.

Fatahillah, A., Puspitasari, I. D., \& Hussen, S. (2020). The development of Schoology web-based learning media with GeoGebra to improve the ICT literacy on quadratic functions. Journal of Research and Advances in Mathematics Education, 5(3), 304316. https://doi.org/10.23917/jramathedu.v5i3.10692

Fithri, D. L., \& Setiawan, D. A. (2017). Analisa Dan Perancangan Game Edukasi Sebagai Motivasi Belajar Untuk Anak Usia Dini. Simetris: Jurnal Teknik Mesin, Elektro Dan Ilmu Komputer, 8(1), 225-230. https://doi.org/10.24176/simet.v8i1.959 
Fitria, A. (2018). Penggunaan Media Audio Visual Dalam Pembelajaran Anak Usia Dini. Cakrawala Dini: Jurnal Pendidikan Anak Usia Dini, 5(2), 57-62. https://doi.org/10.17509/cd.v5i2.10498

Foster, A. (2008). Games and motivation to learn science: Personal identity, applicability, relevance and meaningfulness. Journal of Interactive Learning Research, 19(4), $597-614$.

Hartati, S. (2005). Perkembangan Belajar pada Anak Usia Dini.

Jan, S. (2018). Relationship between students' digital literacy and their attitude towards using ICT. International Journal of Educational Technology, 5(2).

Ljubojevic, M., Vaskovic, V., Stankovic, S., \& Vaskovic, J. (2014). Using supplementary video in multimedia instruction as a teaching tool to increase efficiency of learning and quality of experience. International Review of Research in Open and Distance Learning, 15(3), 275-291. https://doi.org/10.19173/irrodl.v15i3.1825

MacArtney, B., \& Morton, M. (2013). Kinds of participation: Teacher and special education perceptions and practices of inclusion in early childhood and primary school settings. International Journal of Inclusive Education, 17(8), 776-792. https://doi.org/10.1080/13603116.2011.602529

Mayer, R. E., Dow, G. T., \& Mayer, S. (2003). Multimedia Learning in an Interactive Self-Explaining Environment: What Works in the Design of Agent-Based Microworlds? Journal of Educational Psychology, 95(4), 806-813. https://doi.org/10.1037/0022-0663.95.4.806

Mostowfi, S., Mamaghani, N. K., \& Khorramar, M. (2016). Designing Playful Learning by Using Educational Board Game for Children in the Age Range of 7-12:(A Case Study: Recycling and Waste Separation Education Board Game). International Journal of Environmental and Science Education, 11(12), 5453-5476.

Mutia, L., Gimin, G., \& Mahdum, M. (2020). Development of Blog-Based Audio Visual Learning Media to Improve Student Learning Interests in Money and Banking Topic. Journal of Educational Sciences, 4(2), 436. https://doi.org/10.31258/jes.4.2.p.436-448

Nasir, A. M., \& Nirfayanti, N. (2020). Effectiveness Of Mathematic Learning Media Based On Mobile Learning In Improving Student Learning Motivation. Daya Matematis: Jurnal Inovasi Pendidikan Matematika, 7(3), 228. https://doi.org/10.26858/jds.v7i3.11867

Ningrum, G. D. K. (2018). Studi Penerapan Media Kuis Interaktif Berbasis Game Edukasi Kahoot! Terhadap Hasil Belajar Mahasiswa. VOX Edukasi, 9(1), 22-28.

Nofriyanti, Y., \& Sari, H. M. (2019). Implementation of Mathematics Learning Through Media Arrange Smart Dice to Improve Counting Ability in Early Childhood. JPUD - Jurnal Pendidikan Usia Dini, 13(1), 158-171. https://doi.org/10.21009/10.21009/jpud.131.12

Olive, J., Makar, K., Hoyos, V., Kor, L. K., Kosheleva, O., \& STRäSSER, R. (2009). Mathematical knowledge and practices resulting from access to digital technologies. In Mathematics education and technology-rethinking the terrain (pp. 133-177). Springer.

Papadakis, S., Kalogiannakis, M., \& Zaranis, N. (2016). Developing fundamental programming concepts and computational thinking with ScratchJr in preschool education: a case study. International Journal of Mobile Learning and Organisation, 10(3), 187-202.

Papadakis, S., Kalogiannakis, M., \& Zaranis, N. (2018). The effectiveness of computer and tablet assisted intervention in early childhood students' understanding of numbers. An empirical study conducted in Greece. Education and Information Technologies, 23(5), 1849-1871. 
Rachmadtullah, R., Ms, Z., \& Sumantri, M. S. (2018). Development of computer-based interactive multimedia: study on learning in elementary education. Int. J. Eng. Technol, 7(4), 2035-2038.

Rahayu, R., Masrukhan, M., \& Sugianto, S. (2019). Mathematics teaching using generative learning model with character building content aided by interactive learning media. Unnes Journal of Mathematics Education Research, 8(1), 35-48.

Rahmayanti, H., Oktaviani, V., \& Syani, Y. (2020). Development of sorting waste game android based for early childhood in environmental education. Journal of Physics: Conference Series, 1434(1). https://doi.org/10.1088/1742-6596/1434/1/012029

Rendi, R., Sumaryati, S., \& Purwanti, P. (2020). Pengembangan Media Pembelajaran Komik Fisika Materi Pokok Pengukuran Untuk Siswa SMA Negeri 1 Compreng. Navigation Physics: Journal of Physics Education, 2(2), 74-83. https://doi.org/10.30998/npjpe.v2i2.488

Rubiyah, S., Dasmo, D., \& Suhendri, H. (2020). Pengembangan Media Pembelajaran Fisika Berbasis Sparkol Videoscribe dan AVS Video Editor Untuk Siswa Kelas X SMK Mahadhika 2 Jakarta Timur. Schrodinger Jurnal Ilmiah Mahasiswa Pendidikan Fisika, 1(2), 107-118.

Syawaluddin, A., Afriani Rachman, S., \& Khaerunnisa. (2020). Developing Snake Ladder Game Learning Media to Increase Students' Interest and Learning Outcomes on Social Studies in Elementary School. Simulation \& Gaming, 51(4), 432-442.

Taufik, A., Apendi, T., Saidi, S., \& Istiarsono, Z. (2019). Parental Perspectives on the Excellence of Computer Learning Media in Early Childhood Education. JPUD Jurnal Pendidikan Usia Dini, 13(2), 356-370. https://doi.org/10.21009/jpud.132.11

Tella, A. (2007). The impact of motivation on student's academic achievement and learning outcomes in mathematics among secondary school students in Nigeria. Eurasia Journal of Mathematics, Science and Technology Education, 3(2), 149156.

Tsany, U. N., Septian, A., \& Komala, E. (2020). The ability of understanding mathematical concept and self-regulated learning using macromedia flash professional 8. Journal of Physics: Conference Series, 1657(1), 12074. IOP Publishing.

Umar, I. N., \& Jalil, N. A. (2012). ICT Skills, Practices and Barriers of Its Use Among Secondary School Students. Procedia - Social and Behavioral Sciences, 46, 56725676. https://doi.org/10.1016/j.sbspro.2012.06.494

Wardani, F. P., Puspitawedana, D., \& Isnawati, P. (2020). Pengembangan multimedia berbasis salingtemas untuk pembelajaran IPA tema 1 di kelas IV Sekolah Dasar. Navigation Physics: Journal of Physics Education, 1(2), 33-40. https://doi.org/10.30998/npjpe.v1i2.197

Wood, R., \& Ashfield, J. (2008). The use of the interactive whiteboard for creative teaching and learning in literacy and mathematics: A case study. British Journal of Educational Technology, 39(1), 84-96. https://doi.org/10.1111/j.14678535.2007.00703.x

Wulandari, P., Mujib, M., \& Putra, F. G. (2016). Kahoot-Based Learning Game to Improve Mathematics Learning Motivation of Elementary School Students. AlJabar: Jurnal Pendidikan Matematika, 7(1), 101-106. Retrieved from http://ejournal.radenintan.ac.id/index.php/al-jabar/article/view/134/124 